\title{
A COMPARATIVE STUDY ON INTROVERT AND EXTROVERT STUDENTS PERSONALITY IN ENGLISH LISTENING SCORES
}

\author{
Yessi Travolta \\ University of Bengkulu, \\ travoltayessi@gmail.com \\ Mulyadi \\ University of Bengkulu, \\ ladunimulyadi@gmail.com \\ Imranuddin \\ University of Bengkulu, \\ imranulama@gmail.com
}

\begin{abstract}
The objectives of this research were to investigate whether there were any significant differences between introvert and extrovert students on their listening score and to find out which of the students who have better in English listening scores. This research was a descriptive comparative research. The samples of this research were 66 students consisting of 33 introvert students and 33 extrovert students at the fourth semester students of English education study program in Bengkulu University. The instruments of this research were personality questionnaire by Laney (2002) was used to determine the introvert and extrovert personality, and TOEIC Listening simulation was used to find out the students' listening scores. The researcher used SPSS Independent Group t-test with significant level 0.05 . The result of the analysis indicated that Sig. P (2-tailed) was $0.003>$ 0.05. Furthermore, the computation showed that the mean score of introvert was 364.39 , and the mean score of extrovert was 322.12. Therefore, the mean score of introvert group was higher than extrovert group. It could be concluded that the results of the research were: (1) There was significant difference between introvert and extrovert students on their English listening scores, (2) The introvert students have better in English listening score than the extrovert students.
\end{abstract}

Keywords: Descriptive comparative research, personality, introvert and extrovert, listening.

\section{INTRODUCTION}

Personality refers to individual's characteristic which is different from one and another. According to Gazzaniga and Heatherton (2002) personality is someone's characteristic with feelings, thoughts, and behaviors which are formed by the time and the experiences of the individual. Each person has their unique because there is no one people are truly alike. Jung in Laney (2002) defined the personality into two types: introversion and extroversion.

Introversion is an individual's characteristic which orientates of ideas, emotions, and impressions (Laney, 2002). They can be categorized as closed-minded students. It means that they prefer working 
independently instead of staying in a group. While, extroversion is an individual's characteristic which orientates of people, activities, and things out of the individual (Laney, 2002). They have open-minded characteristics. They are actively involved with a group of people because they tend to be talkative in their daily life. Therefore, Suparman (2010:68) stated that the extrovert students tend to be better speakers than the introverts.

Since the beginning of 1990s, there has been a growth of interesting on how personality is related to the academic performance. It is supported by Murray and Mount (1996, p. 270) stated that individual's personality can influence the students' achievement in acquiring the second and foreign language. Furthermore, Wengrum (2013) said that students who have introvert and extrovert personality have different achievement in speaking performance. It means that introversion and extroversion personality affects the students' achievement in English language.

Nowadays, most people take personality test to find out what the skills they master based on their personality. Unfortunately, in school and college, student's personality has not considered in teaching learning process enough. In fact, personality should be studied by the language teachers in understanding the students' characteristic in order to create more fruitful learning. According to Lestari (2013) there is a correlation between the personality of the student, the learning style and the learning strategy that the student develops in order to achieve better academic achievement.

As English foreign language, one of the main goals in EFL instruction is to train the learners to be able to understand their interlocutor. As Tyagi (2013) said that good listening skill makes the students more productive because the first thing that should be faced by the students is hearing.
This is supported by Chastain (1988) who stated that to learn how to speak, learners should be able to understand the spoken language they hear firstly. Therefore, listening is very important skill both in the learning process or social communication. Unfortunately, there are several aspects which influence the students' achievement in listening. Anderson \& Lynch (1988) stated that one of the factors which influence the listening achievement is the students' character or personality.

Personality becomes an important role in acquiring foreign language both in school or college. In college, the personality has formed strongly made the students' characteristic. It is supported by Wan (2011) said that personality can be changed by maturational processes. Through the college activities, learners tend to become more conscientious and quite. It is because the learners have aware of their personality. This is the important moment to find out the effect of personality towards the learning achievement.

The problem that always exists in learning English listening is the differences scores among the students. In fact, it was found at the fourth semester students in English study program of Bengkulu University. They have passed two years in learning English language, but they still have different achievement in listening scores. As EFL students, the fourth semester students have not background of learning English intensively before. They just have acquired and produced English language intensively from the first semester. It meant that they have learnt English language for two years, but the difficulties and differences are still faced by the students.

From the observation, the researcher has found that there were different scores between students either class A or B class. The Students who got high score in listening I tend to get high score in listening II. Meanwhile, they were received same 
treatment and training from the lecturers. Now on, however, in listening III at the fourth semester, there was still a significant different among the students' scores in classroom. Truthfully, they both have been studying English for two years and through listening major in the class for twice.

As students of English language study program, they must have good listening ability in order to compete the global challenge and as the different from other study programs. Therefore, they should measure their listening ability level. To find out the level in English foreign language, the students can take a standardized test. There are several kinds of standardized tests such as TOEIC, TOEFL, and EILTS. The researcher has asked the students about the standardized tests. Truthfully, they have not been already taken one of the standardized tests yet. They ought to take TOEIC test as least. Then, this study preferred to choose TOEIC listening test to measure the students' scores rather than TOEFL or EILTS. It was because the level of TOEIC test is lower and appropriate for the sample.

Furthermore, this study has several previous studies which were relevant to the present research. Andriyani (2016) found that students with introvert personality have better in the reading comprehension than extrovert students. In contrast result by Mall-Amiri \& Nakhaie (2013) with the title Comparing the Performance of Extrovert and Introvert Intermediate Female EFL Learners on Listening and Reading Tasks. The result indicated that introverts perform significantly better in listening tasks than extroverts. Another one came from Muharrami (2013) compared the introvert and extrovert students in listening achievement. It proved that introvert personality has better achievement in listening ability. But, contrary to Ratminingsih (2012) indicated that there was no significant difference between the group of students who used the game technique and those who used the song technique. The students who have extrovert personality are better than the students who have introvert personality in English listening skill.

From the previous studies, this study wanted to conduct the research at English study program at University level without considerate the gender and age of students. This study would focus only on listening skill at fourth semester because several considerations. By considering that fourth semester have learned and trained deeper listening class at second and third semester so that they have ability and same level in listening skill. The other was college students have capability to determine their personality. Furthermore, this research would adopt the difference introvertextrovert questionnaire from previous study, and used TOEIC listening simulation test as second instrument. The reason behind choosing TOEIC as the instrument, it was because the sample has already learnt about the kinds of questions in TOEIC test.

Based on explanation above, this research presented the research questions as below:

1) Are there any significant differences between introvert and extrovert students in their listening scores based on Laney's theory (2002)?

2) Which students of introvert and extrovert are better in English listening scores?

\section{METHOD}

The design of this research was a descriptive comparative research. Descriptive comparative research is a research that compares one or more variables on two or more difference measurements, or on difference time (Sugiyono, 2016, p. 36). In this research, the researcher compared the significant difference between introvert and extrovert groups of the fourth semester students in English education study program of 
Bengkulu University and their achievement in TOEIC listening scores. There were two variables that have been organized in this research: the dependent and independent variables.

The population of the research was including all fourth semester students in English Study Program of Bengkulu University in class year of 2015/2016. It consisted of two classes: A and B class with 76 students. After the numbers of introvert and extrovert students were known from the result of the questionnaire, the researcher got 66 students as the sample. The researcher used total sampling technique because all of the populations were taken as samples.

In collecting the data, this research has two kinds of instruments; Personality Questionnaire from Laney (2002) and TOEIC listening simulation test. Laney personality questionnaire (LPQ) was used to find out the students' personality. Laney personality questionnaire (LPQ) was originally consisted of 30 items. To check the validity and reliability of the Laney Personality Questionnaire (LPQ), the researcher used three experts and tried out. The three experts were one Psychology lecturer and two English lecturers. Laney personality questionnaire was tried out to 31 students at the sixth semester who have the same characteristics with the sample of the research. The result of try out was analyzed through the Stastical Package for Social Science (SPSS 21). The result showed that LPQ had high validity proved by 33 item's validity was more than 0.355 and high reliability in which the value of Cronbach Alpa was 0.844 .

The second instrument was TOEIC listening simulation. TOEIC Listening simulation was used to find out the students' scores. Furthermore, to find out the validity and reliability of TOEIC listening simulation, the researcher tried out to 10 students of fourth semester. SPSS 21 was used to analyze the data. From the result of analysis, the researcher found that all items of TOEIC listening scores was valid proved by the score of items' validity was more than 0.3. Then, the Cronbach Alpa was 0.959 meant the TOEIC had high reliability to be used. Therefore, there were 100 questions as the second instrument.

The data were analyzed using SPSS 21 to find out whether the hypothesis was rejected or accepted. Independent t-test two-tailed with the level of significance $\alpha=$ 0.05 was used. The proposed hypothesis was:

$\mathrm{HO}=$ There is no significant difference between introvert and extrovert students with their scores of listening.

$\mathrm{H} 1=$ There is significant difference between introvert and extrovert students with their scores of listening.

The criteria were:

$\mathrm{H} 1$ is accepted : (H1 : sig. $\mathrm{p}<0.05)$

$\mathrm{HO}$ is accepted : (HO : sig. $\mathrm{p}>0.05$ )

Before testing the hypothesis of this research, the researcher would like find out the normality and homogeneous data. According to Arikunto (2010), to analyze the data using interval ratio, the data should be normal and homogeneous. Therefore, the normality and homogeneity of the data were tested firstly.

\section{RESULTS AND DISCUSSION}

\section{a. Laney Personality Questionnaire}

The personality questionnaire was done to classify the sample into two groups: introvert and extrovert group. Laney Personality Questionnaire (LPQ) was answered by 76 students by choosing four possible answers: Never, Sometimes, Often, and Always. From the result of the average percentage between introvert and extrovert items, out of 76 students who followed Laney Personality Questionnaire, 40 students were from class $A$ and 36 students were from class $B$. Class $A$, there were 21 introvert students and 19 extrovert 
students. From class B there were 22 introvert students and 14 extrovert students.

In order the introverts and extroverts students should have the same number respectively. Therefore, the researcher took all students with extrovert personality. They were 19 extrovert students from class $A$ and 14 extrovert students from class B. Then, there were 33 extrovert students as sample. Because the number both of two groups must be the same, the researcher took 33 introvert students, 19 introvert students from class $A$ and 14 introvert students from class B. Hence, there were 13 introvert students who were dropped from the sample.

After the sampling was done, the researcher got the result of total sample as below:

Table 1. The result of Laney Personality

\begin{tabular}{|l|c|c|c|l|}
\multicolumn{1}{|c|}{ Questionnaire } \\
\cline { 2 - 5 } Groups & \multicolumn{2}{|c|}{ Class } & $\Sigma$ & Percentage \\
\hline $\begin{array}{l}\text { Introvert } \\
(x 1)\end{array}$ & 19 & 14 & 33 & $50 \%$ \\
\hline $\begin{array}{l}\text { Extrovert } \\
(x 2)\end{array}$ & 19 & 14 & 33 & $50 \%$ \\
\hline Total & & 66 & $100 \%$ \\
\hline
\end{tabular}

Then, there were 66 students as samples which divided into two group; they were 33 students in introvert group and 33 students in extrovert group.

\section{b. The Result of a TOEIC Listening Simulation Test}

The second data were obtained from the results of TOEIC listening simulation that consists of 100 questions in 45 minutes. From the results of TOEIC listening score were classified into two groups: introverts and extroverts. Later, TOIEC scoring system was used in order to count the TOEIC simulation score. The students' scores was divided into six levels or categories; they are 5-125 (novice), 130-200 (elementary), 205300 (intermediate), 305-390 (basic working proficiency), 395-450 (advanced working proficiency), 455-495 (general professional proficiency). The result of the TOEIC listening test can be seen in table of each personality.

Table 2. TOEIC listening test of introvert and extrovert group

\begin{tabular}{|l|l|l|}
\hline Score & $\begin{array}{c}\text { Number of } \\
\text { Introvert } \\
\text { group }\end{array}$ & $\begin{array}{c}\text { Number of } \\
\text { Extrovert } \\
\text { group }\end{array}$ \\
\hline $455-495$ & 0 & 0 \\
\hline $395-450$ & 12 & 1 \\
\hline $305-390$ & 15 & 22 \\
\hline $205-300$ & 6 & 8 \\
\hline $130-200$ & 0 & 2 \\
\hline $5-125$ & 0 & 0 \\
\hline Total & 33 & 33 \\
\hline \multicolumn{2}{|c|}{ Source: from Pustaka Baru Press (2015) }
\end{tabular}

Based on the table 2, this research found out that the TOEIC listening simulation scores gotten by the students ranged from 225 to 440. For the total sum score from 33 students' scores for introvert group was 11.680. Meanwhile, the listening scores were gotten by the extrovert students ranged from 140 to 400 . For the total sum score from 33 students' scores for introvert group was 10.630 .

\section{c. Requirements Data Analysis Testing}

\section{Normality Data Testing}

According to the result of normality analysis test which used one-sample Kolmogorov-Smirnov test in SPSS 21. Then the sample of normality test results was obtained as follows:

Table 3. The result of normality data

\begin{tabular}{|l|l|}
\hline & Unstandardized Residual \\
\hline $\mathrm{N}$ & 66 \\
\hline Kolmogorov-Smirnov Z & 1.266 \\
\hline Asymp. Sig. (2-tailed) & .081 \\
\hline
\end{tabular}

The result of normality test with Sig. (2-tailed) was 0.81. Thus, normality hypothesis test was sig. (2-tailed) $>0.05$. H1 was accepted, the data distribution was normal.

\section{Homogeneity Data Testing}


After finding the normality of the data, this research analyzed the homogeneity test using ANOVA ONE WAY in SPSS 21, the result is below:

Table 4. The result of homogeneity data

\begin{tabular}{|l|l|l|l|}
\hline $\begin{array}{c}\text { Levene } \\
\text { Statistic }\end{array}$ & \multicolumn{1}{|c|}{ df1 } & \multicolumn{1}{c|}{$\mathrm{df2}$} & \multicolumn{1}{c|}{ Sig. } \\
\hline .098 & 1 & 64 & .755 \\
\hline
\end{tabular}

From the table 4 above, this research found that Sig. $P$ was 0.755 . As criteria of hypotheses is if Sig. $\mathrm{P}>0.05$ so that $\mathrm{H} 1$ is accepted, the data is homogeneous. From the result in table above, Sig. P was $0.755>$ 0.05 so that $\mathrm{H} 1$ was accepted, both of introvert and extrovert group were homogeneous.

\section{d. Hypothesis Test}

The hypothesis testing using SPPS 21 which has been established, the independent t-test with two-tailed can be continued. With the $5 \%$ significance criteria are as follows:

Sip. $\mathbf{P}>\mathbf{0 . 0 5}=\mathrm{HO}$ is accepted; $\mathrm{H} 1$ is rejected, there is no significant difference between introvert and extrovert group in English listening score.

Sip. $\mathbf{P}<\mathbf{0 . 0 5}=\mathrm{HO}$ is rejected; $\mathrm{H} 1$ is accepted, there is significant difference between introvert and extrovert group in English listening score.

Table 5. The result of Independent t-test

\begin{tabular}{|l|c|l|l|}
\hline \multicolumn{4}{|c|}{ t-test for equality of mean } \\
\hline & $\mathrm{t}$ & $\mathrm{df}$ & $\begin{array}{l}\text { Sig. (2- } \\
\text { tailed) }\end{array}$ \\
\hline $\begin{array}{l}\text { Equal } \\
\text { variances } \\
\text { assumed }\end{array}$ & 3.407 & 64 & $\mathbf{0 . 0 0 3}$ \\
\hline $\begin{array}{l}\text { Equal } \\
\text { variances } \\
\text { not } \\
\text { assumed }\end{array}$ & 3.407 & 63.671 & 0.003 \\
\hline
\end{tabular}

The result of computation showed that the Sig. (2-tailed) was 0.003. It meant that students' score of introvert and extrovert group was significantly difference since Sig. (2-tailed) < a $(0.003<0.05)$. To answer the first research question of this present research, based on the results, it could be concluded that the $\mathbf{H} \mathbf{1}$ is accepted since Sig. $P<0.05$, so that there is significant different between introvert and extrovert group in English listening score.

Furthermore, to answer the second question which one of the two groups has better in English listening scores. The difference could be seen from the mean scores both of groups as table below:

Table 6. The mean scores of Introvert and Extrovert groups

\begin{tabular}{|l|l|c|l|}
\hline & \multicolumn{1}{|c|}{ Group } & N & \multicolumn{1}{|c|}{ Mean } \\
\hline \multirow{2}{*}{ Score } & Introvert & 33 & 364.39 \\
\cline { 2 - 4 } & Extrovert & 33 & 322.12 \\
\hline
\end{tabular}

From the mean score table 6 above, the researcher found the mean score of introvert group was 364.39 , while the mean score of extrovert group was 322.12. It meant that the mean score of introvert group was 364.39, it was higher than extrovert group was 322.12 . It could be concluded that the introvert group has better achievement than extrovert group in English listening scores.

\section{DISCUSSION}

This research discussed some interesting findings dealing with the students' personality questionnaire, the students' English listening scores represented by TOEIC listening results, and the comparative between introvert and extrovert group in English listening scores as the main result of this research.

From the result of the Questionnaire, this research found that the totals of introvert students that exist at the fourth semester are more than total of extrovert students. It meant that students with the introvert personality are mostly dominant than students with extrovert personality at the fourth semester students in English Study Program of University Bengkulu. 
Wijaya (2016) stated that personality level mostly dominated by introvert personality in the college life in Indonesia. For more specific, Salihah (2016) found out that personality that existed at the seventh semester of English Education Study Program in Universitas Bengkulu was highly Introvert. From the same finding of the previous studies, it can be said that all of the introvert and extrovert personality traits grow more influenced by age.

The main result is about the comparison between introvert and extrovert group in English listening scores. The researcher used IBM SPSS 21 in analyzing the data. Then, independent t-test with significant level 0.05 was used to compare the TOEIC listening scores on introvert and extrovert students at fourth semester of English Education Study Program in Bengkulu University. It revealed that there was significant difference between introvert and extrovert group in English listening scores. From the mean score of TOEIC listening simulation test, it proved that introvert students have better scores in English listening test than extrovert ones. This research assumed that it happened because of several reasons that exist in introvert and extrovert personality.

The first reason comes from the different characteristics between them. Introvert students would rather listen than talk, and tend to be more concentrated and detailed in doing something. While the extrovert students do not like to stay too long in doing something because they are impatient and quick to feel bored (Laney, 2002). Extrovert prefers direct action involving the physical and energetic. Therefore, it does not suit with the learning listening skill that requires high concentration and patience, as well as high accuracy in capturing and interpreting the information obtained. When answering TOEIC listening questions, the students need to focus and stay for long time in hearing the
100 questions. It is one of reasons why extrovert students in the fourth semester of the English Education Study Program are not better than introvert students in listening scores.

The other one is the way they express their feeling or emotion. Introverts prefer to work alone than in a group, they do not like being in the center of attention (Burrus and Kaenzig, 1999). They feel uncomfortable to interact with a lot of people in order that they love spend time by themselves like reading a book, listening a music or writing a story. They enjoy doing something by themselves. On the other hand, extrovert students work best in classrooms that allow time for discussion, talking or working with a group (Lestari, 2013). They like involving in a crowd, group or activities outside themselves. Therefore, asking them to stay and hear the TOEIC listening make them get pressure and like living under a thick of cloud. Thus, the introvert students at the fourth semester of English Education Study Program have higher scores than the extrovert students.

The findings in this present research are in line with the several previous studies. The first was conducted by Mall-Amiri \& Nakhaie (2013) which indicated that there was significant difference between introvert and extrovert students with listening tasks, but there was no significant difference with reading tasks. He found that the introvert students were better than extrovert students in listening skill at Soodeh Language School and Kish Institute. The second came from Muharrami (2013) who found that there was significant difference between introvert and extrovert group in listening achievement at the first grade of SMA Kartika Metro. Introvert group has higher score in listening tasks than extrovert group. Furthermore, the result of this present study is also similar to Alavinia (2012) which indicated that there was a significant relationship between listening 
ability with the students' personality: extroversion vs. introversion. It showed that the more introvert the subjects, the better their performance on listening.

Then, the next, previous studies were in different skills of the present research. Qomaruddin (2010) studied about correlation between extraversion personality and English writing skill. The result showed that there was a positive correlation between extrovert and introvert students with their writing skill. It meant the more introverted someone, the higher writing scores that they had. Then, Andriyani (2016) showed that there was a significant difference between introvert and extrovert students. She proved that the introvert students got better results in reading comprehension test than the students with extrovert personality.

Furthermore, Lestari (2013) who found a moderate correlation between the extrovert-introvert personalities dimensions with the students' speaking performance. The extrovert students have better performance in speaking skill. However, the other one is contradictory to the result of this present study. It comes from Ratminingsih (2012) who indicated that there was no significant difference in the listening skill between the students who learn using the game technique and the song technique. The students who have extrovert personality got better than introvert personality. The difference findings between this present research and the fifth previous study can be caused by several aspects.

The first aspect is the instruments of the research. Ratminingsih used games and songs as listening test, while this present research used TOEIC listening simulation to measure the students' listening scores. The other aspect is the difference samples from this present study. She conducted at SD Lab UNDIKSHA Singaraja in the first semester in the 2009/2010 academic year for six months with the total number of 12 effective teaching lessons. Meanwhile, this present research conducted at the fourth semester students of English Education Study Program in Bengkulu University.

Because the samples of the seventh previous study were elementary students who did not have background of English listening skill, so that they might get difficulties in catching the information. As Alavinia (2002) said that older students and higher grade students get more probability in obtaining higher scores. After all, it might be predictable that older students may enjoy more powerful abstract thinking which may lead to more cogent reasoning while listening. On the other hand, the older students have turned the maturational process so that the personality has formed strongly. Since the personality occurs because of maturational processes (Wan, 2011).

Throwing back to the same findings with the five previous studies, in could be concluded that the special characteristics of introverts: like high concentration, good attention to detail, their eagerness to listen rather than to speak make them easier to obtain the information. Then, they have learnt and familiarized with the kind of questions in the TOEIC listening test were administered could help them to achieve better scores than extroverts in doing listening test. The difference of English listening scores outcomes in the two groups is due to the difference characteristics in each group. Extrovert students with all of the characteristics led them into the outside world, and the other side is introvert students who lead them into inside of themselves have impacts on the listening learning process. Based on the same and difference findings from previous studies, the researcher concluded that introvert students have better performance in listening, reading, and writing skills, while extrovert students have better in speaking skill. 
This present research was related to some limitations. Since this research focus on the students' listening scores, focusing a study in other sub-skills could be have different result. The researcher conducted the personality questionnaire from Laney (2002) to determine the introvert and extrovert personality, and TOEIC listening simulation to find out the students' listening scores. Therefore, this research has recommendations for further researches. Further researches may look for other skills or sub-skills in conducting the next research. The researcher also recommends conducting further research is not only in English department, but also in difference department.

After finding that the introvert and extrovert personality was one of factors which can influence the students' scores in English listening skill, the lecturer and teacher should consider them in teaching and learning process. The lecturer must realize that every student is unique. They have their own ways in learning English which gives strengthens and weaknesses during the process. The educators should not expect students to have the same result on different language skills. It is because all the external and internal conditions are not the same. To get more precise assessment of the students' results, the students' psychological aspects should be taken into serious consideration in English teaching and learning process.

\section{CONCLUSIONS}

Referring to the discussion of the research in the previous part, the result showed that there is any significant difference between introvert and extrovert students personality in English listening scores by using TOEIC listening simulation test. The difference is significant enough which can be seen from Sig. (2-tailed) was higher than 0.05, it means that there is significant difference between introvert and extrovert group in English listening scores.

Furthermore, the result of the mean score both of introvert and extrovert group showed that the introvert students got higher mean score than the extrovert students. Thus, the researcher draws a conclusion that the introvert students have better performance in English listening scores than the extrovert students at the fourth semester students of the English Education Study Program in Bengkulu University.

\section{SUGGESTIONS}

Related to the result of this research, it is suggested that the English lecturers should give more attention to the extrovert students in teaching listening. Lecturers can create playful activities that involve physical and action in teaching English listening skill. It is because the extrovert students work best when they can speak up. Therefore, lecturers should speak more when teaching listening skill. Speaking and listening is integrated skills, they cannot be separated. Thus, in teaching listening lecturers should combine speaking and listening in order to make introvert and extrovert students get better in acquiring listening achievement.

Furthermore, for the students, they should know their personality so that they can establish the appropriate techniques or strategies in learning English listening. The students should understand themselves, especially in what skill they are good at, and what skill they lack. Then, they should more concern and also spend more time to master English skill that they are lack off. Thus, they can improve themselves to achieve success in mastering all the English skills.

This research found that introvert students got better result on listening score than extrovert students. For further research, the researcher suggests to analyze why introvert and extrovert personality can influence speaking skill. It is because 
previous study stated that extrovert students were better performance in speaking skill. It will be a good idea to investigate why introvert students were not better than extrovert students in speaking skill. Speaking and listening skill are integrated skill, so investigating the factors that influence the introvert students in speaking skill will help introvert students also get better in speaking skill.

\section{REFERENCES}

Alavinia, P. (2016). Potential bonds between extroversion/introversion and Iranian EFL learners' listening comprehension ability. English Language Teaching Journal, Vol. 5, No. 5; May 2012.

Anderson, A., \& Lynch, T. (1988). Listening. Oxford: Oxford University Press.

Andriyani, R. P. (2016). Comparative study of reading comprehension between students with introvert and students with extrovert personality. Kalianda, Lampung: Lampung University.

Arikunto, S. (2010). Prosedur penelitian sosial suatu pendekatan praktik. Jakarta: PT. Rineka Cipta.

Burruss, J. D., \& Kaenzig, L. (1999). Introversion: the often forgotten factor impacting the gifted. Virginia Association for the Gifted Newsletter, 21(1).

Furqon, M., Rizka, H., \& Hidayati, N. N. (2015). Top one preparation of TOEIC to reach the highest score. Yogyakarta: Pustaka Baru Press.

Gazzaniga, Michael S., \& Heartherton, Todd F. (2002). Psychological science: The mind, brain, and behavior. New York: United States of America.
Mall-Amiri \& Nakhaie. (2013). Comparing the performance of extrovert and introvert intermediate female EFL learners on listening and reading tasks. Iran: Islamic Azad University of Central Tehran Branch.

Muharrami, M. L. (2013). A comparative study between introvert and extrovert students in listening achievement at the first grade of SMA KARTIKATAMA METRO. Bandar Lampung: University Lampung.

Laney, M. O. (2002). The introvert advantage: How to thrive in an extrovert world. New York: Workman Publishing.

Lestari, A. (2013). Analysis of the relationship of extrovert-introvert personality and students' speaking performance. Pontianak: Tanjungpura University.

Qomarudin, A. (2010). Correlation between extraversion personality and english writing skill. Semarang: Universitas Diponegoro.

Ratminingsih, N. M. (2012). Teaching technique, types of personality, and English listening skill. 2329. Retrieved from http://journal.um.ac.id/index.php/jip/a $\underline{\text { rticle/view/3379 }}$

Salihah, R. (2016). Efl learners' learning styles at the seventh semester of English study program Universitas Bengkulu. Bengkulu: Universitas Bengkulu.

Sugioyono. (2016). Metode penelitian pendidikan: Pendekatan kuantitatif, kualitatif, dan $R \& D$. Bandung: Alfabeta. 
Suparman, U. (2010). Psycholinguistic: The theory of language acquistion. Bandung: Afrino Raya.

Tyagi, B. (2013). Listening: An important skill and its various aspects. The Criterion An International Journal in English ISSN 0976-8165, Issue $12(2)$.

Wan, K. E. (2011). Does personality remain stable or change over time?. Civil Service College Singapore Blog Website.

Wengrum, T. D. (2013). Comparative study of students' reading comprehension to understand narrative text between extrovert and introvert students' personality at the first grade of SMA Negeri 1 Seputih Banyak. Bandar Lampung: Universitas Lampung, Unpublished Script.

Wijaya, R. S. (2016). Perbandingan penyesuaian diri mahasiswa berkepribadian ekstrovert dan introvert. Jurnal Penelitian Tindakan Bimbingan Dan Konseling Vol. 2, No. 2, Mei 2016. 